IZA DP No. 10109

Migration and Globalization:

What's in it for Developing Countries?

Hillel Rapoport

July 2016 


\title{
Migration and Globalization: What's in it for Developing Countries?
}

\author{
Hillel Rapoport \\ PSE, Université Paris 1 Panthéon-Sorbonne, \\ $M P C$, European University Institute, CEPII and IZA
}
Discussion Paper No. 10109
July 2016

IZA

P.O. Box 7240

53072 Bonn

Germany

Phone: +49-228-3894-0
Fax: +49-228-3894-180
E-mail: iza@iza.org

Any opinions expressed here are those of the author(s) and not those of IZA. Research published in this series may include views on policy, but the institute itself takes no institutional policy positions. The IZA research network is committed to the IZA Guiding Principles of Research Integrity.

The Institute for the Study of Labor (IZA) in Bonn is a local and virtual international research center and a place of communication between science, politics and business. IZA is an independent nonprofit organization supported by Deutsche Post Foundation. The center is associated with the University of Bonn and offers a stimulating research environment through its international network, workshops and conferences, data service, project support, research visits and doctoral program. IZA engages in (i) original and internationally competitive research in all fields of labor economics, (ii) development of policy concepts, and (iii) dissemination of research results and concepts to the interested public.

IZA Discussion Papers often represent preliminary work and are circulated to encourage discussion. Citation of such a paper should account for its provisional character. A revised version may be available directly from the author. 
IZA Discussion Paper No. 10109

July 2016

\section{ABSTRACT \\ Migration and Globalization: What's in it for Developing Countries?}

This paper reviews a growing literature on migration and globalization, focusing on its relevance for developing and emerging economies. It documents the role of diaspora networks in enhancing cross-border flows of goods, capital, and knowledge, eventually contributing to efficient specialization, investment, and productivity growth in the migrants' home-countries. Particular attention is paid to the role of skilled migrants, and to information imperfections reduction as the main channel for the documented effects. Overall, the evidence suggests that migrants contribute to the integration of their home-countries into the global economy.

JEL Classification: F21, F22, F63, J61, O11, O15

Keywords: migration, globalization, trade, FDI, financial flows, knowledge diffusion, development

Corresponding author:

Hillel Rapoport

Paris School of Economics

University Paris 1 Panthéon-Sorbonne

106-110 Boulevard de l'Hôpital

F-75013 Paris

France

E-mail: hillel.rapoport@psemail.eu 


\section{Introduction}

Globalization is characterized by the general increase in international flows of goods, input factors, technology and financial assets, with all these components growing consistently more rapidly than output. According to this definition there have been two episodes of globalization so far in modern economic history: the first episode took place during the late nineteenth and early twentieth century, and the second episode is currently ongoing and started roughly thirty years ago. In both episodes, the growth rate of international trade largely exceeded the rate of output growth, leading for example to a tripling of the world trade/GDP ratio in just a few decades, between 1960 and 2005. As can be seen from Figure 1, the share of the foreign-born population living in the OECD area has also tripled (from about 3 to 10 percent) in just a few decades, more or less at the same pace as the world trade/output ratio. The liberalization of international capital movements followed and translated into even bigger relative increases in investment flows. This holds true independently of whether one looks at capital as a production factor (i.e., FDI) or at other private international financial flows, for example in the form of purchases of portfolio assets (see below for detailed figures).

There is however one big difference between the two episodes, and one which has largely been overlooked by most observers. While the first era of globalization has been termed "the age of mass migration" (Hatton and Williamson, 1998), the present era is an era of globalization for everything except people. Indeed, the share of people living in a country which is different from their country of birth (this is the standard definition of immigration) has remained remarkably stable over the last four decades, around 3 percent of the world population (Ozden et al., 2011). In other words, the number of migrants worldwide has increased more or less at the same pace as the world population since WWII. Comparatively, therefore, the world appears much less open to migration than a century ago, at a time when international migration was essentially free and the share of migrants in the world population was two to three times higher than what it is today (Livi-Bacci, 2012). 
Figure 1: Evolution of the world trade/output ratio and of the share of foreign-born in the OECD population, 1960-2005

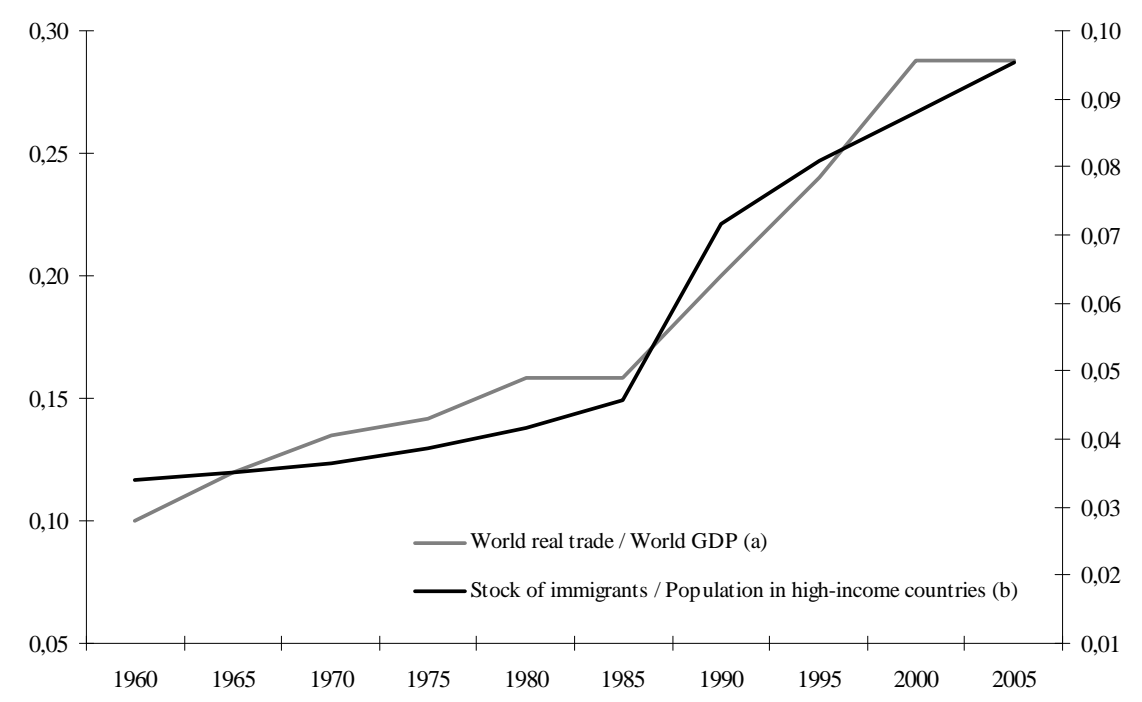

Figure 1 shows the increase in global trade as a share of global output (on the left axis) and the stock of immigrants in OECD countries as a share of the overall population in OECD countries between 1960 and 2005 (on the right axis).

This is not to say that migration plays a minor role in the current episode of globalization. On the contrary, the role of migration is as essential as before - but qualitatively different. Indeed, most of the migration that took place in the age of mass migration saw poor emigrants leaving old Europe to settle in the new countries. As the term indicates, the demographic extraction on certain European countries was quantitatively massive - significantly reducing the population size and demographic growth of sending countries. For example, the annual mean gross emigration rate per 1000 inhabitants from 1860 to 1913 was 9.25 for Italy, 4.61 for Great-Britain and 1.5 for Germany (Hatton and Williamson, 1998). In contrast, most of today's migration takes place from developing to developed countries (i.e., South-North migration). While this represents a quantitatively important development from the perspective of the receiving economies, the opposite is not true: from the perspective of sending countries, the number of people extracted by migration is simply not commensurate to the numbers brought by demography.

The reason why emigration is essential for developing countries today, therefore, lies elsewhere; it has to do with the two following facts. First and as already mentioned, an increasing fraction of international migration today is South-North; if one excludes "artificial" migration arising from the 
partition of certain countries (e.g., former Soviet Union Republics), South-North migration now represents more than 50 percent of total world migration. This means that through migration, developing countries connect themselves to the most economically and technologically advanced countries of the world economy. As is well known, once migration networks start forming, they facilitate bilateral economic transactions through their removing of informational and cultural barriers between host and origin countries. This "diaspora externality" has long been recognized in the sociological literature and then by economists in the field of international trade. These networks create bridges between countries, and along those bridges many things can circulate: goods, capital, technology, ideas, and -- of course -- more people.

Second, an increasing fraction of South-North migration is highly-skilled. The number of college educated immigrants born in a developing country and living in an OECD host country has more than doubled between 1990 and 2000 (Beine et al., 2007) and now represents more than 40 percent of South-North migration. This explosion in the numbers has not depleted the stock of human capital remaining in developing countries: as shown on Figure 2, the intensity of the brain drain has only slightly increased in most regions (and even decreased in some), mostly thanks to strong progress in educational attainments worldwide. While the early literature on skilled emigration and human capital accumulation has shown a pessimistic picture, promoting the idea that the brain drain can delay economic progress in developing countries (e.g., Bhagwati and Hamada 1974, Miyagiwa 1991), the more recent literature has re-approached the issue of brain drain, proposing new theoretical modeling (and founding empirical support) for the idea that a country's stock of human capital is endogenous to the prospect of emigration, hence the incentive-creating aspects of the brain drain on human capital formation (e.g., Mountford 1997, Beine, Docquier \& Rapoport 2001).

The paper will focus more on the rise of international skilled migration and its significance for middle- and low-income countries not so much because of the challenge of brain drain but, rather, because of the opportunities that such emigration pattern represents in terms of increased trade, capital inflows, and technology transfers to developing countries. ${ }^{1}$ These are the growth ingredients brought about by globalization that developing countries need the most, and skilled emigrants have a strong comparative advantage in "shipping" them to the home country. This is the viewpoint

\footnotetext{
${ }^{1}$ See Docquier and Rapoport (2012) for an overview of skilled emigration and growth in source countries.
} 
presented in the rest of this paper, with the following structure: Section 2 and 3 will review the literature on the effect of migration on trade and foreign direct investment, respectively, with Section 4 bringing the three dimensions (trade, FDI, migration) into a unified theoretical framework. Section 5 will discuss the importance of migration for other financial flows. Section 6 reviews the empirical literature on migration-based knowledge diffusion across countries and Section 7 concludes.

\section{Figure 2: Intensity of the brain drain (as share of human capital stock) by region, 1975-2000}

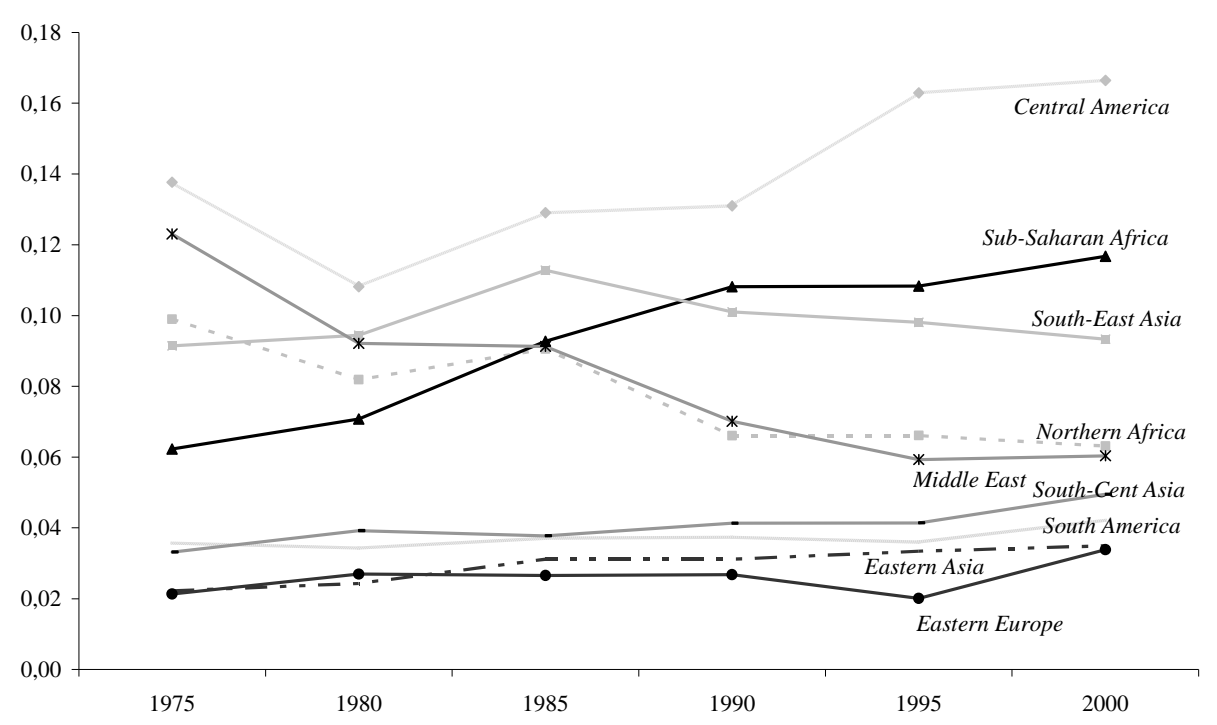

\section{The trade-creating effect of migration}

Recent literature in the field of international trade shows that migration networks have strong tradecreating effects. There are at least two channels through which immigration has been shown to affect trade flows. The first mechanism is related to an information effect. immigrants can increase bilateral imports and exports because they help overcoming information problems thanks to their having a better knowledge of their origin and host-country markets, the connections and knowledge about the respective institutional and business environments, as well as the linguistic skills that are needed to start and develop import and export activities across countries. Previous literature has mainly focused on this effect by showing that the role of ethnic networks is more important for differentiated than 
for homogenous products (see for instance Rauch and Trindade, 2002; Rauch and Casella, 2003; and Felbermayr and Toubal, 2012). The idea behind this mechanism is that ethnic networks are likely to reduce information costs - for instance, through more efficient matching and referral services - and these costs are likely to be larger for differentiated goods. The second channel through which immigration can affect trade flows is a preference effect (also denoted as "ethnic-goods" channel). Immigrants can generate additional demand for goods from their source countries, both directly, through their own consumption (as when, in their utility function, they attach a higher weight to the consumption of products from their origin country), or indirectly, by affecting natives' preferences (through a diffusion of preferences effect).

In many instances, therefore, trade and migration appear as complements (e.g., Gould, 1994, Head and Ries, 1998, Combes, Lafourcade and Mayer, 2005, Iranzo and Peri, 2009). While these studies provide evidence that migration networks have trade-creating effects, they do not consider specifically highly skilled migrants. An exception is Felbermayr and Jung (2009), who use bilateral panel data on trade volumes and migration by education levels and find a significant pro-trade effect of migration: a one-percent increase in the bilateral stock of migrants raises bilateral trade by 0.11 percent. However they do not find significant differences across education groups. Koenig (2009) confirms the trade-creating effect using firm-level data on French exports. She shows that this effect is enhanced when immigrants are older and more educated.

The above studies all use bilateral data on trade and migration to analyze the effect of the latter on the former, relying mostly on the time-structure of the data (that is, using migration networks formed long before the trade flows analyzed took place) for identification, as well as on a rich set of heterogeneous effects (e.g., homogeneous v. heterogeneous goods, imports v. exports, skilled v. unskilled migrants) that constitute both plausibility tests and allow for richer interpretation of the results. The suspicion, however, is that there may be bilateral omitted factors that drive the joint pattern of trade and migration that may be time-invariant (and, hence, not addressed when using lagged values); or, for firm-level data, that forward-looking firms planning to expand their activities in certain countries would recruit workers from these countries ahead of their trade expansion. It could also be that migration affects trade through FDI, an issue we will address in the next section.

What the literature was really lacking until recently, therefore, is a natural experiment allowing to gauge the trade-creating effects of migration in a way that could address the above concerns. This is 
now available thanks to the work of Parsons and Vezina (forthcoming), who confirm the tradecreating effect of migration using the natural experiment of the Vietnamese boat people. These refugees were randomly assigned residence in the US after the fall of Saigon in 1975 and spent their first years in the US at a time the US had an embargo on trade with Vietnam. The networks formed at that time proved instrumental in fostering US exports to Vietnam after the embargo was lifted in the mid-1990s, with US States with larger networks consistently exporting more to Vietnam than States which received lower amounts of Vietnamese refugees. The authors convincingly show that the allocation of refugees across US States can be considered exogenous (and certainly independent of future trade links with Vietnam) and that all of the effect can be attributed to trade in heterogeneous goods, which is suggestive of the role of networks in removing information barriers. ${ }^{2}$

To illustrate their findings, we present two figures taken from their paper. Figure 3 shows the timing of the events. It plots the immigration waves of Vietnamese to the US (dotted line), with three spikes corresponding to the Fall of Saigon, the Sino-Vietnamese War and later the introduction of US policies designed to welcome additional waves of Vietnamese refugees. These massive immigration shocks preceded the opening up of trade with Vietnam in 1994, which led to a rise in US exports to Vietnam (bold line) that was particularly pronounced in the late 2000s. To show that the rise in trade with Vietnam is largely due to migration networks, Parsons and Vezina (forthcoming) instrument the size of the Vietnamese networks by US States using the first wave of refugees only, those who were randomly assigned residence in the late 1970s, and then proceed with a regular gravity exercise for bilateral exports between US States and Vietnam. Their empirical results confirm the causal effect of Vietnamese immigrants on US exports to Vietnam, whether measured as a share of total exports or as share of GDP. The coefficients suggest an elasticity of trade to migration around 20 percent, about double the magnitude obtained in non-experimental cross-country studies. Figure 4 illustrates this pro-trade affect by plotting for each US State their predicted Vietnamese network (based on the early, exogenous allocation of Vietnamese refugees) and exports to Vietnam during the period 19952010, after the trade embargo on Vietnam was lifted. The circles indicate the size of the network.

\footnotetext{
${ }^{2}$ In a similar spirit, Steingress (2015) analyzed the impact of migration on US imports of intermediary goods across all US states in the period between 1970 and 2005, using two types of instruments: the allocation of refugees as part of the US refugee resettlement program, and the migration inflows from Central America to the US caused by the Hurricane Mitch in 1998. Steingress finds a consistently positive impact of migration on the import of intermediary goods across US states over time.
} 
Figure 3: Vietnamese inflows to the US and US Exports to Vietnam

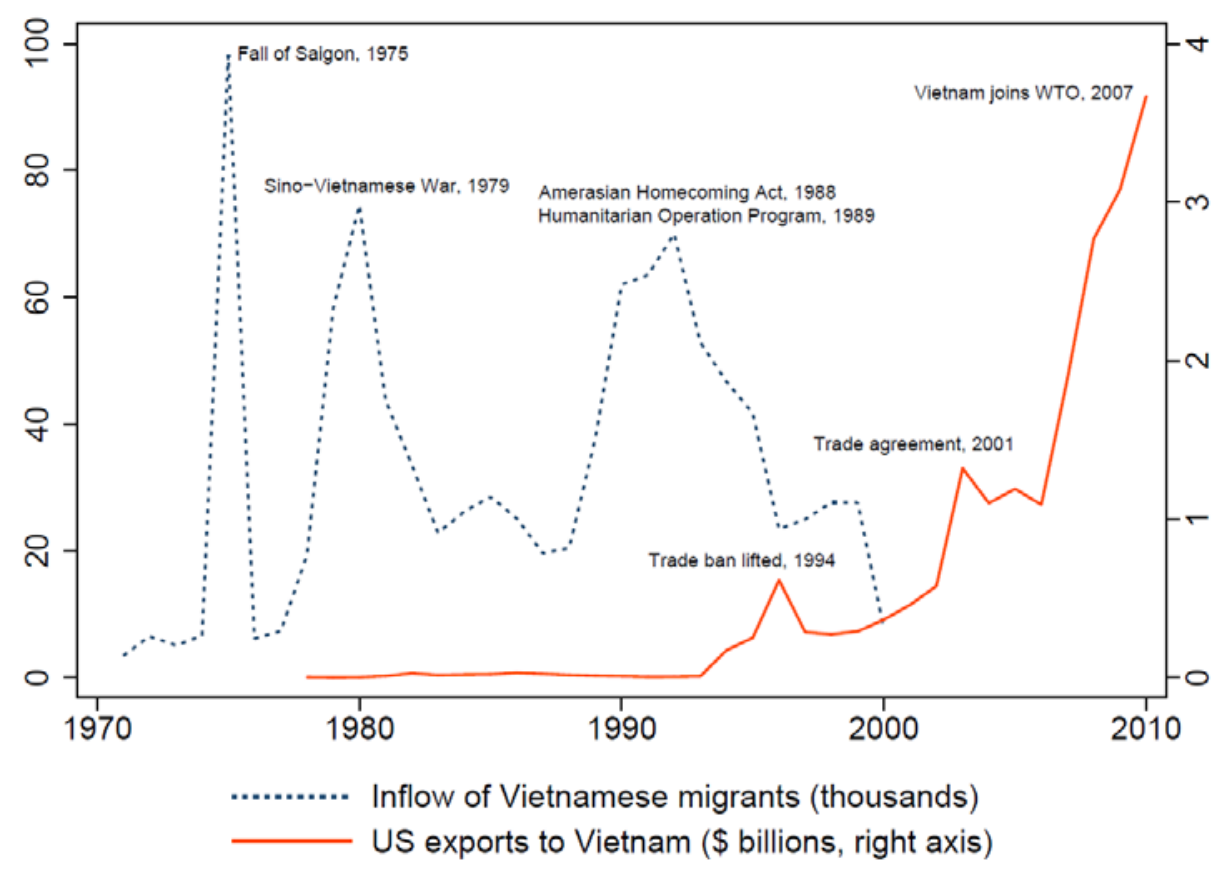

Figure 4: Pro-Export effect of the Vietnamese Exports to Vietnam

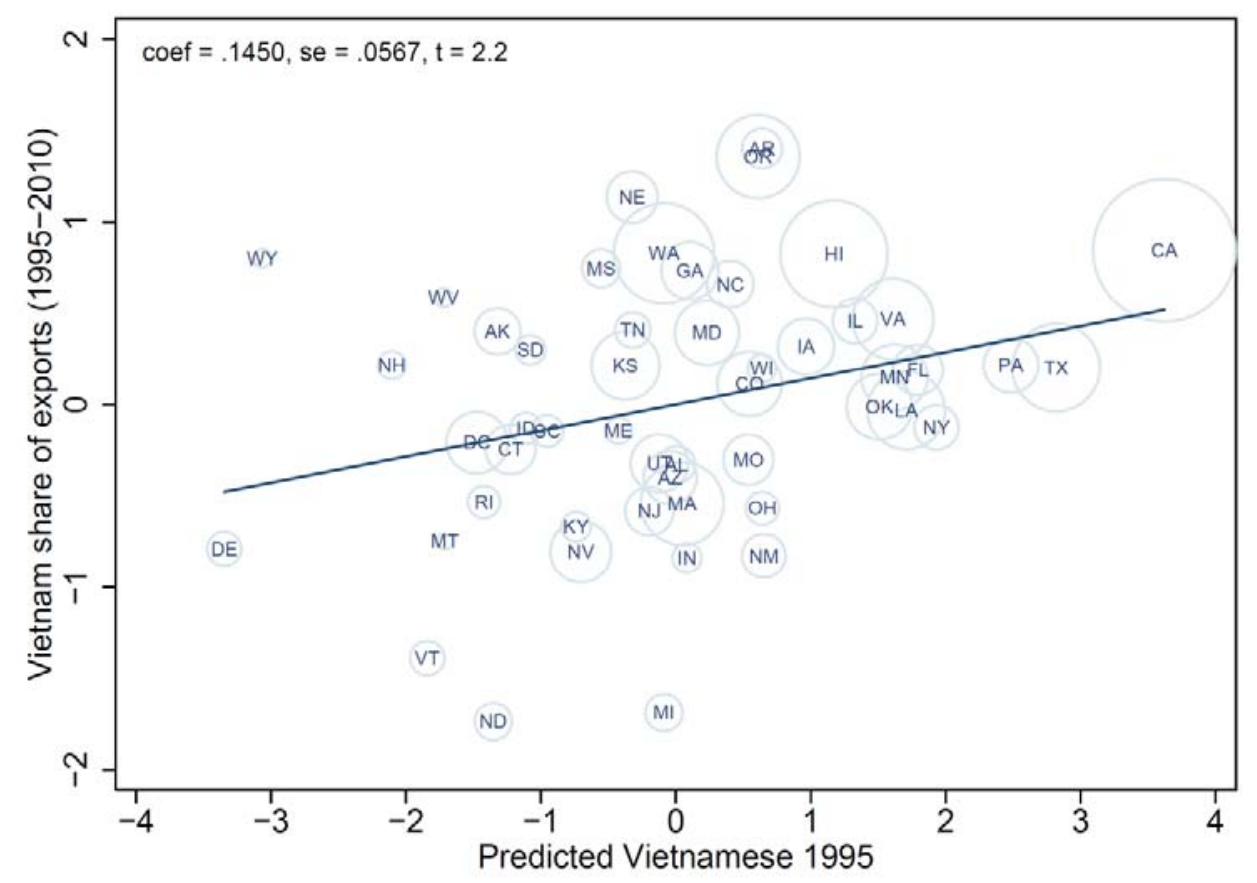




\section{Migration and FDI}

Foreign Direct Investments (FDI) have always existed, however it is generally considered that it is only with the start of the present globalization episode, in the late 1980s, that they became sizable and emerged as a major source of capital for emerging and developing countries (Lipsey et al. 1999). It is therefore natural to ask whether countries that had a pre-existing migration and diaspora networks benefitted more than others from those capital inflows.

Let us first document the rise of FDI in the recent period, especially the rise of FDI to non-OECD destinations, which have recently surpassed those within the OECD, both in volume and in growth. These investments are mainly directed to Middle Income Countries or Emerging Economies in Asia and Central America while only a small proportion is invested in Low Income Countries in Southern Africa and the Middle East (see Figures 5 and 6). Disentangling the Private Capital Flows among Emerging Markets, China clearly stands out as the main recipient of international financial flows. Emerging Economies in Europe have experienced a remarkable increase in inflows of private capital in the first half of the 2000s, even overtaking China. However, the financial crises in 2007 and the currency crises in 2012 have weakened the position of European EMs significantly (see Figure 3).

\section{Figure 5: FDI outflows from $\mathrm{OECD}$ countries to different world regions}

(Source: World Development Indicators and author's own calculations)

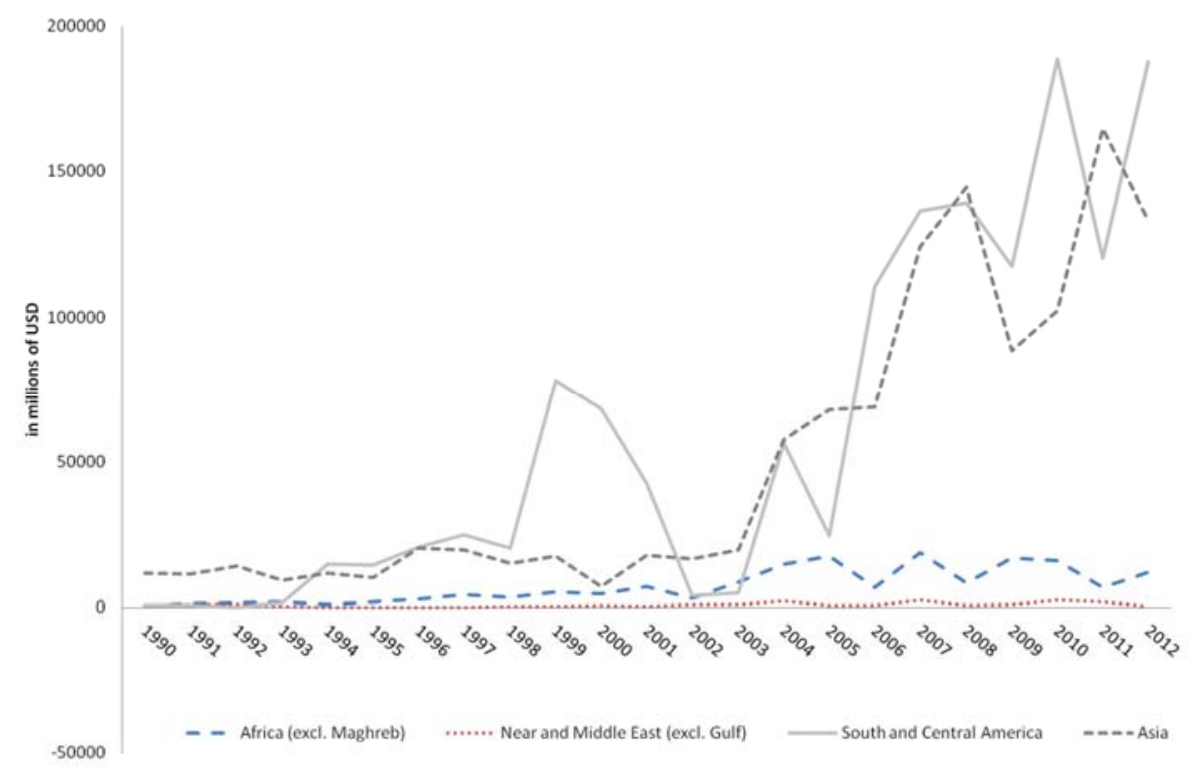


Figure 6: OECD FDI outflows to OECD and non-OECD countries

Source: World Development Indicators and author's own calculations

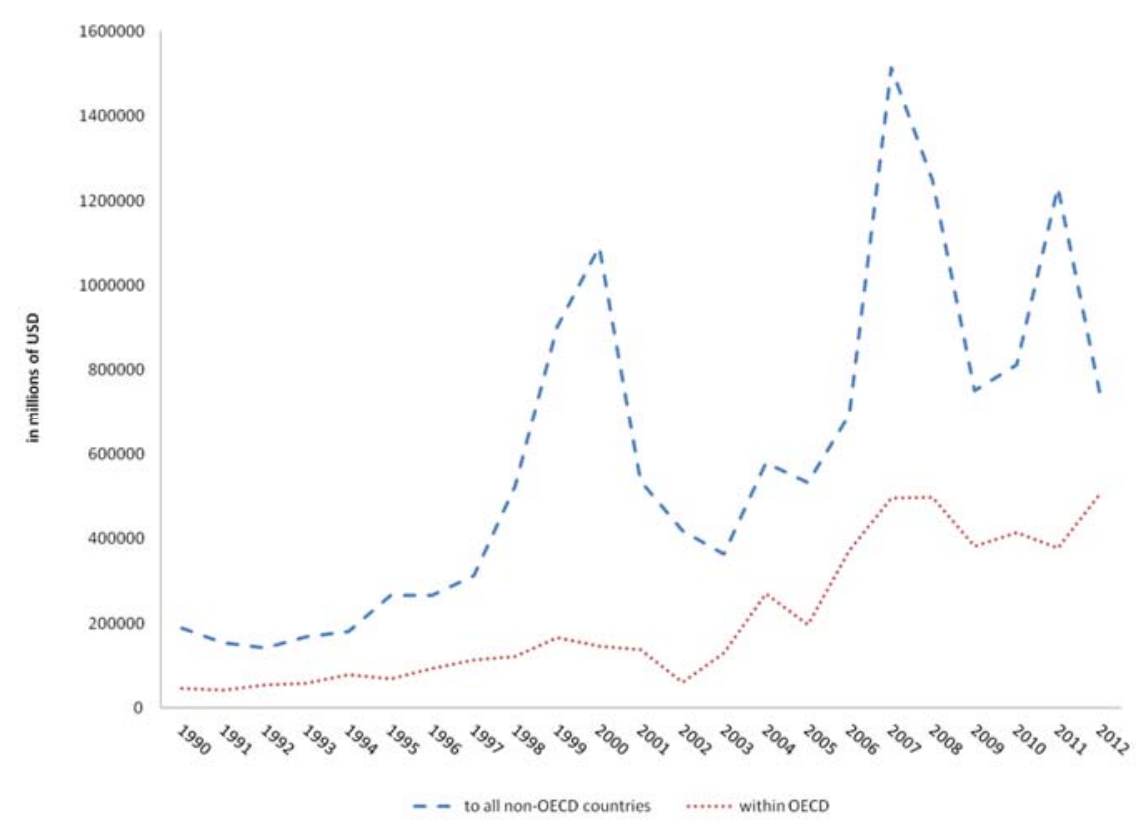

Migration may facilitate the formation of the types of business links which lead to FDI project deployment in a particular location. The sheer presence of migrants in a host country can be a catalyst to establish the required links to achieve efficient distribution, procurement, transportation and satisfaction of regulations. While the channel just described would seem to apply mainly to skilled migrants, unskilled migrants may also contribute to relax information constraints on FDI. Indeed, participation in the destination country's labor force reveals information about the characteristics of workers in their home country, thereby reducing uncertainty about the profitability of FDI.

The first studies to explore the links between migration and FDI focused on sectoral and regional case studies. For example, Aroca and Maloney (2005) find a negative correlation between FDI flows and low-skill migration between the border states of Mexico and the United States (i.e., substitutability) while in the spirit of Rauch's work on trade, Tong (2005) finds that ethnic Chinese networks promote FDI between South-East Asian countries and beyond, especially where institutional quality is relatively high. The first paper to introduce the skill dimension of migration in a bilateral setting is Kugler and Rapoport (2007). Using bilateral FDI and migration data, they 
investigate the relationship between migration and FDI for U.S./rest of the world flows during the 1990s. The authors use US census data on immigration stocks by country of origin and educational level for 1990 and 2000 and FDI outflows by destination country and sector from the US Bureau of Economic Analysis. The dependent variable is change in each country's sectoral capital stock that may be attributed to the accumulated FDI of US origin (e.g. the growth rate of US financed capital stock). This is regressed on the stock of migrants in the United States originating from country $i$ in 1990, on the log-difference of the change of that stock between 1990 and 2000, and a number of standard control variables (including regional fixed effects). Their results show that manufacturing FDI toward a given country is negatively correlated with current low-skill migration, as trade models would predict, while FDI in both the service and manufacturing sectors is positively correlated with the initial U.S. high-skill immigration stock of that country. Javorcik et al. (2011) confirm these results after instrumenting for migration using passport costs and migration networks with a thirtyyear lag.

Finally, at a micro level, Foley and Kerr (2011) quantify firm-level linkages between high-skill migration to the United States and U.S. FDI in the sending countries. They combine U.S. firm-level data on FDI and on patenting by ethnicity of the investors and find robust evidence that firms with higher proportions of their patenting activity per formed by inventors from a certain ethnicity subsequently increase their FDI to the origin country of the inventors. They use ethnicity year fixed effects to control for unobserved heterogeneity, and also instrument the ethnic workforce share in each firm using city level data on invention growth by ethnicity. They find that a one percent increase in the extent to which a firm's pool of inventors is comprised of a certain ethnicity is associated with a 0.1 percent increase in the share of affiliate activity conducted in the country of origin of that ethnicity. This provides firm level evidence of a complementary relationship between high-skill immigration and multinational firms' activity.

\section{Migration, Trade, and FDI in a unified framework}

Following Brainard (1997), a large literature in the field of trade has confirmed the complex relationship between trade and FDI (see for instance Blonigen (2001), Helpman et al. (2004), and Hanson et al. (2005)). Kugler and Rapoport (2011) therefore propose to investigate the relationships between trade, migration and FDI in a unified framework; they do so while acknowledging the role 
of firms' heterogeneity (Melitz, 2003) in determining the margins of trade (that is, the selection of trade partners, the selection of firms - or extensive margin - and the volume of trade/FDI - or intensive margin). Their theoretical model is based on Helpman, Melitz and Yeaple (2004) and their empirical model on Helpman, Melitz and Rubinstein (2008).

Helpman et al. (2004) construct a model of monopolistic competition with firm heterogeneity, where every firm randomly draws its production unit cost $\alpha$ from cumulative Pareto distribution. A firm can decide to just produce domestically, it can also export its goods, and it can undertake Foreign Direct Investments. These options are associated with different costs (fixed cost of entry, fixed overhead labor cost if firm chooses to produce, and the firm can either choose to serve foreign market with exports or with FDI, each given their respective fixed cost). The authors' model ensures that (1) it is profitable for all firms to serve the domestic market, (2) the most productive firms engage in FDI, and (3) the less productive firms engage in exporting, and the least productive firms only serve domestic market, as shown on Figure 7. There are two important productivity thresholds in this model: a first critical productivity threshold characterizes the firm for which it is profitable to export, and a second, higher productivity threshold which characterizes the firm for which it is more profitable to serve the foreign market through FDI than through exports. These thresholds are noted respectively $\frac{1}{a^{X}}$ and $\frac{1}{a^{I}}$ in the technical discussions below.

Kugler and Rapoport (2011) extend Helpman et al. (2004) to include the role of migrant networks. Indeed, the presence of migrants is likely to alter the decision to start exporting or forming a subsidiary abroad. As discussed in the previous sections, migration networks facilitate the penetration into a foreign market by providing business links or by simplifying administrative burdens. Hence, the collection of this information might encourage more firms to start either to export or to set up a subsidiary abroad, increasing the number of firms selling on the foreign market. Migrant networks can also affect the volume sold abroad by firms already present in the foreign market by decreasing the variable trade cost. Kugler and Rapoport (2011) therefore decompose the effect of migrant networks into its effect on lowering: the variable trade costs of exporting, the fixed cost to penetrate the foreign market and the fixed cost to set up a subsidiary abroad. Such breakdown enables to identify how migration networks affect the aggregate decision on the mode to serve the foreign market (that is, either through exports or FDI, if any). 
The key question, then, is the following: how does the composition and volume of FDI and exports change in response to an exogenous increase in the stock of migrants? The answer is theoretically uncertain: if the information and opportunities created by migrant networks enable to decrease more the cost of setting up a subsidiary abroad, one would expect observing an increase in the share of firms investing abroad; on the contrary, if the relevant information reduces more the cost of trading between the two countries, we should expect firms switching from affiliate sales to exports. Decomposing the different effects, the authors find that migration only affects FDI-related sales through the extensive margin (that is, through the choice of mode of entry in the foreign market). The way this translates in terms of sales either through exports or through sales by foreign subsidiaries, however, is ambiguous. If migration networks decrease all fixed and variable costs symmetrically, then it can be shown that the ratio of FDI-sales to exports should increase. In other words, and unless one consider cases where migration networks disproportionately reduce the costs of shipping goods (hence favoring exports), which seems unrealistic, one can expect that more migration will increase FDI more than exports.

Figure 7 intuitively shows why this is the case, focusing on the extensive margin (that is, the proportion of firms serving the foreign market by each mode of entry). A proportional decrease in the fixed costs moves the productivity thresholds of both exports and FDI, $\frac{1}{a^{X}}$ and $\frac{1}{a^{I}}$ to their new positions $\frac{1}{a^{X^{*}}}$ and $\frac{1}{a^{I^{*}}}$ to the left. Note that a proportional decrease reduces the productivity threshold by the same factor, therefore $\frac{1}{a^{I}}$ moves more to the left than $\frac{1}{a^{X}}$ does (as it is higher to start with). Before the decrease, the share of firms doing FDI is given by the area A and that doing exports by the area $\mathrm{B}+\mathrm{C}$. After the decrease, these shares respectively become $\mathrm{A}+\mathrm{B}$ and $\mathrm{C}+\mathrm{D}$. When $\mathrm{A}(\mathrm{B}-\mathrm{D})+\mathrm{BB}>0$, the ratio of number of firms in FDI to exports increases as the fixed cost decreases. The model shows this is always verified under the conditions of the Helpman et al. (2004) framework (in particular, if one assumes that the distribution of firms is a Pareto-distribution).

The main implication of the model, therefore, is that the ratio of FDI-related sales to exports by the firms of a country $i$ in the market of country $j$ should increase when there is more migration from $j$ to $i$. Kugler and Rapoport (2011) then test this (and other secondary) predictions in a gravity framework 
using recent bilateral data on migration, trade and FDI. They find that migration - and especially skilled migration -- positively affects trade and FDI (at both the extensive and intensive margins), and more so for the latter, resulting in an increase in the FDI to trade ratio, as predicted by their model.

Figure 7: Effect of migration on the extensive margin: exports $v$ FDI

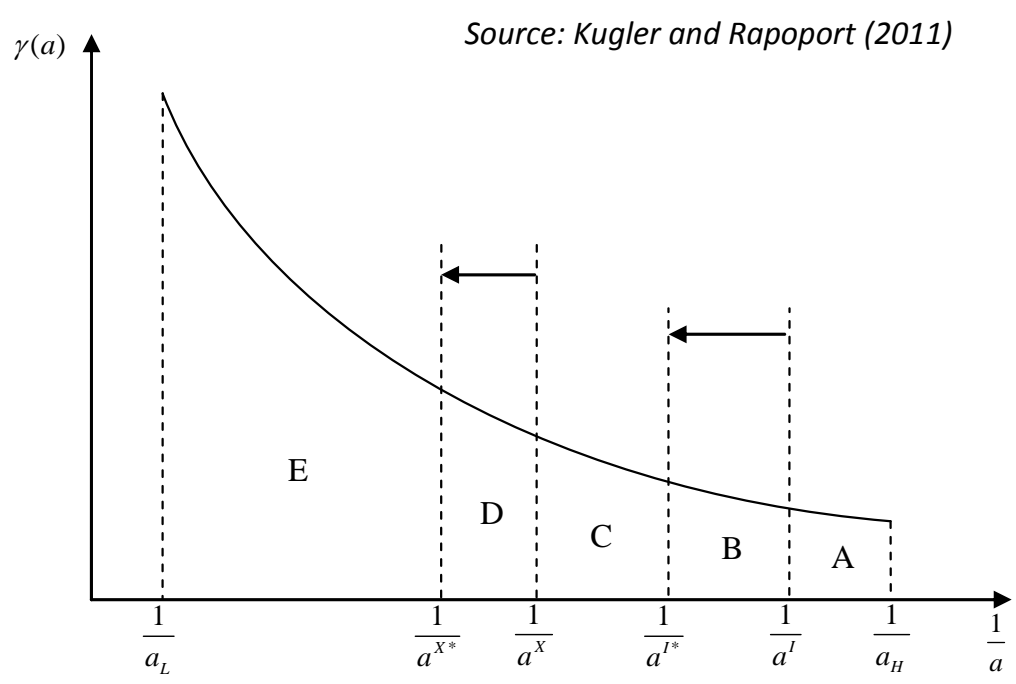

In addition to the theoretical model, the authors test its empirical predictions and construct a data set comprising of all pairs between 203 countries for the period between 1948 and 2006. They find that an increase in the stock of immigrants by $1 \%$ will increase the export to their country of origin by $8 \%$. This trade creating effect of migration is even higher for skilled immigrants and is consistent with the results from previous studies cited in Section 2. The corresponding elasticity for FDI is around $20 \%$, indicating that FDI is more sensitive to migration than trade. Finally, the elasticity of the FDI to exports ratio with respect to migration is around 15 percent. This means that for a given increase in migration from country $j$ to country $i$ there is a propensity for FDI from $i$ to $j$ to grow 15 percent more than exports from $i$ to $j$. These results suggest the importance of migration for the formation of international networks for business information diffusion and with the fact that skilled migration rather than total migration has the strongest impact on FDI. 


\section{Migration and Financial Flows}

FDI is only one component of overall cross border financial flows, which usually also include portfolio debt and equity, as well as bank activities and other financial transactions. The main difference in the composition of cross-border capital flows in the most advanced economies versus emerging markets is that FDIs play a much larger role in emerging markets (see Figures 8 and 9 for the breakdown of financial flows to developing countries by type and region).

Regarding capital flows to developing countries, FDI still make up a significant share on overall flows. However, financial flows, including Official Development Assistance and concessional and non-concessional loans, are still one of the main components on overall capital flows to Low Income Countries. Like in advanced and emerging economies, capital flows have experienced a drastic decline after the financial crisis but have now recovered to be at a level more than double as high as in 2003.

Figure 8: Cross Border Capital Flows by type in Developing Countries

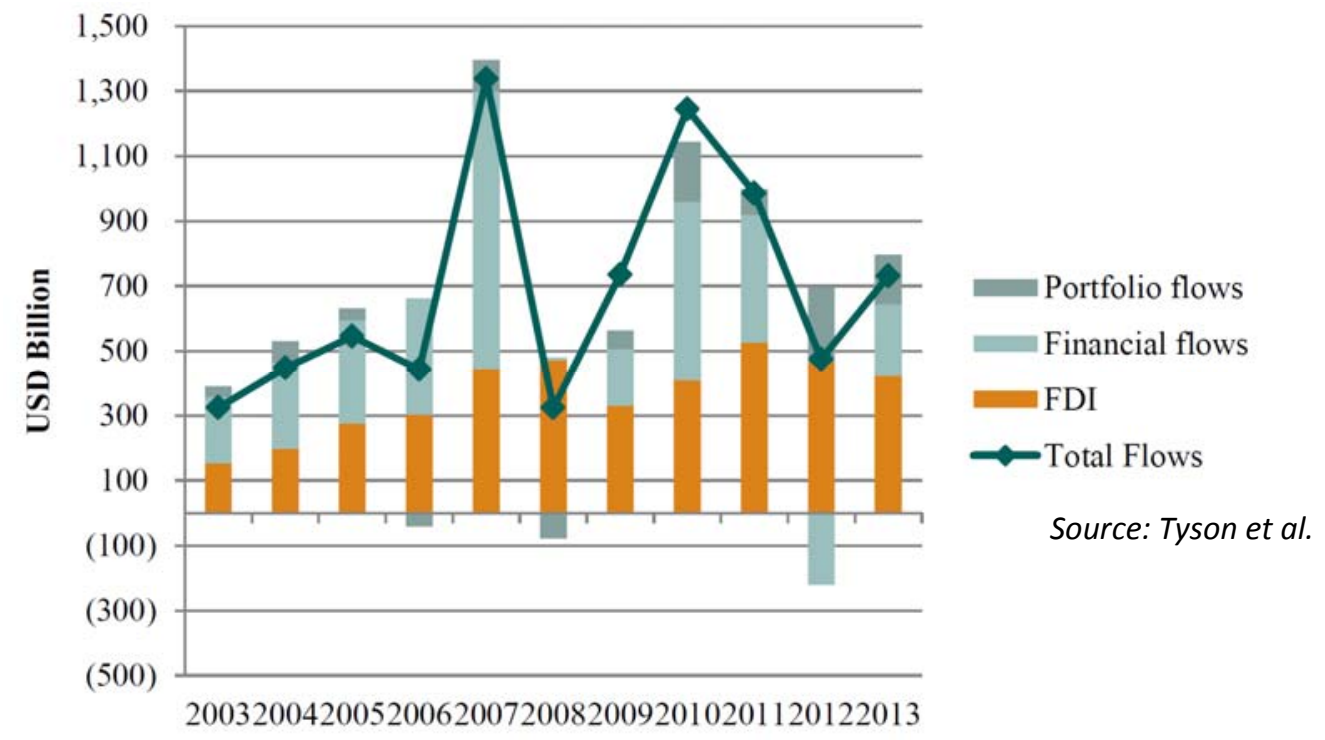


Figure 9: Private Capital Flows (FDI + Portfolio Investment) to Emerging Markets (in Billions of USD and Share of EM's GDP)

Source: Institute of International Finance

Source: Institute of International Finance

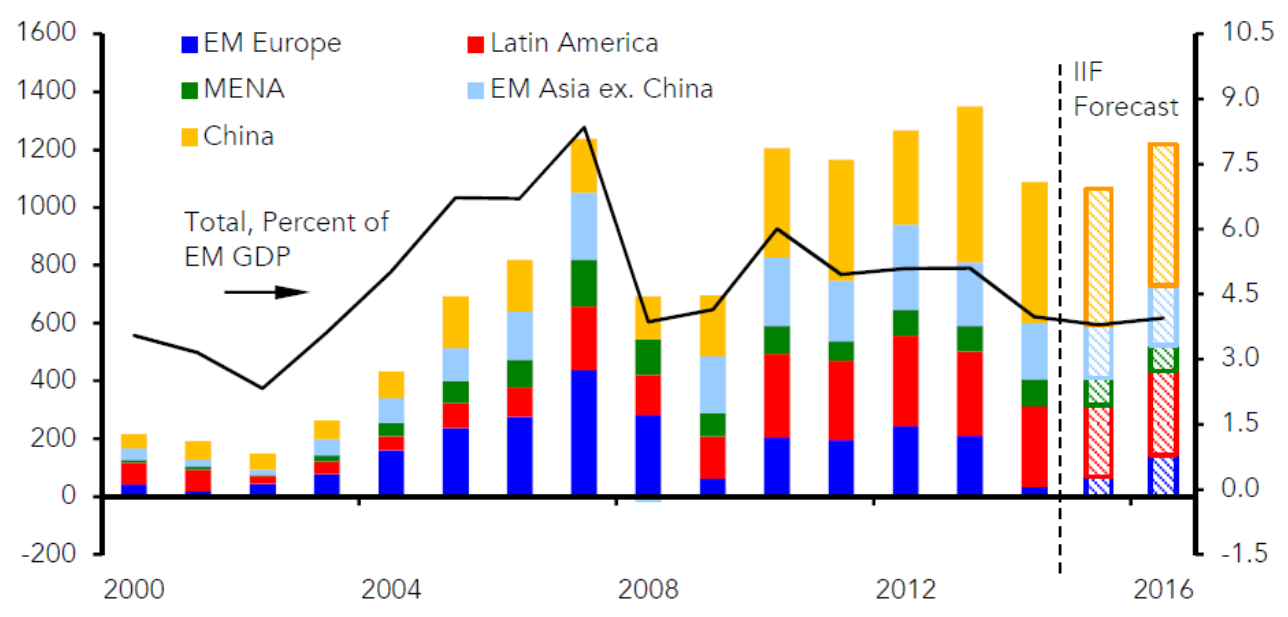

As we did for trade and FDI flows, we may ask whether and how migration affects financial flows other than FDI and whether the effect of migration, if any, may also be attributed to the information channel. Previous literature has emphasized the role of gravity forces in determining the pattern of international financial flows. A key role in this literature is assigned to informational frictions. Gravity variables that affect the extent of such frictions (e.g., lower distance, common language, common legal origin, etc.) have consistently been shown to increase bilateral financial flows and mitigate home bias (Coeurdacier and Rey, 2013). Portes and Rey (2005) and Lane and Milesi-Ferretti (2008) show this for cross-border equity flows. Aviat and Coeurdacier (2007) extend the analysis to bank loans, equity flows and bond holdings.

Kugler, Levintal, and Rapoport (2015) investigate the role of migration as a determinant of international financial flows. They introduce migration into a standard gravity model and find a positive impact on financial flows. Their paper posits that the cross-border movement of people reduces informational frictions across countries and stimulates bilateral financial flows. This is due to the fact that migration from country $j$ to country $i$ has the potential to reveal information on country $j$ which is valuable for investors in country $i$ (e.g., information on the characteristics of the home country's financial and political institutions), as argued above for FDI. In addition, migrants may 
create or integrate into international business and financial networks, thereby enhancing financial transactions between their home and host countries.

Their empirical strategy relies on the estimation of differential effects along a number of dimensions: a skill dimension, a cultural dimension, and an asset-type dimension. They start by showing that migration has a significant positive impact on international bank loans. Distinguishing between skilled and unskilled migrants, the authors find a significantly stronger impact for skilled migration. For example, when introducing skilled and unskilled migrants jointly to a gravity model of international bank loans, they find a significant positive elasticity of skilled migrants of about 0.2 while no significant effect is found for unskilled migrants. This result is in line with the idea that the skilled migrant diaspora is more likely to foster bilateral financial cooperation through business ties, as they are typically more integrated into the financial and labor market.

To rule out the possibility that the results reflect effects that go from migration to trade and from trade to financial flows, they estimate a differential effect of skilled versus unskilled migrants on exports. While such heterogeneous effects are present in the case of financial flows, they are absent in the case of trade. This result confirms that the differential effect on financial flows is not driven by trade.

Next, they allow for the effect of migration to vary with the degree of cultural proximity. The authors find that the effect of migration is nearly zero for country pairs that share a common language, colonial history or legal origin, and positive otherwise. These results are consistent with the view that the potential for migration to alleviate informational frictions is higher for culturally distant countries. They are also able to distinguish between foreign investments in long versus short term bonds. Arguably, the longer term to maturity of the former makes them riskier and more information sensitive. The authors find that the effect of migration on investment in long term bonds is indeed significantly stronger compared to short term bonds. Actually, for short term bonds they do not find a significant effect of migration, whereas the elasticity of investment in long term bonds with respect to migration is positive, significant and economically meaningful at 0.14-0.16, depending on specification (see Table 1). 
Table 1: Effect of migration on long term versus short term bonds (KLR, 2015)

\begin{tabular}{lcccc}
\hline Dependent variables: & $\begin{array}{c}\log (\text { Long bonds }) \\
(1)\end{array}$ & $\begin{array}{c}\log \text { (Short bonds }) \\
(2)\end{array}$ & $\begin{array}{c}\text { Long bonds } \\
(3)\end{array}$ & $\begin{array}{c}\text { Short bonds } \\
(4)\end{array}$ \\
\hline $\log$ (Migration) & $0.164^{* *}$ & 0.073 & $0.147^{* * *}$ & 0.108 \\
$\log$ (Distance) & $(0.072)$ & $(0.095)$ & $(0.030)$ & $(0.069)$ \\
& $-0.446^{* * *}$ & $-0.812^{* * *}$ & $-0.304^{* * *}$ & -0.114 \\
$\mathrm{~N}$ & $(0.106)$ & $(0.134)$ & $(0.071)$ & $(0.082)$ \\
$\mathrm{L}$ & 541 & 541 & 1,517 & 1,517 \\
$\mathrm{~B}$ & 31 & 31 & 31 & 31 \\
$R^{2}$ & 85 & 85 & 92 & 92 \\
Estimator & 0.90 & 0.74 & 0.95 & 0.94 \\
\hline
\end{tabular}

This table estimates the effect of migration on investment in long term bonds and short term bonds. $N, L$ and $B$ denote number of observations, number of lending (investing) countries and number of borrowing (issuing) countries, respectively. Regressions are estimated by OLS and Poisson. Standard errors are clustered at the borrowing country level. All columns include country fixed effects, colonial link, language and legal origin as additional controls.

Regarding the context of developing countries more specifically, Kugler et al. (2015) expect the effect of migration to have the greatest potential where information imperfections are more pervasive, that is, in developing countries. And indeed, when they interact the migration variables with a dummy for developing country status, the authors find a magnified effect coming mostly from the extensive margin (see Table 2).

Table 2: Comparison between Developed and Non-Developed Countries (KLR, 2015)

\begin{tabular}{lcc}
\hline Dependent variables: & $\begin{array}{c}\log (\text { Loans }) \\
(1)\end{array}$ & $\begin{array}{c}\text { Loans } \\
(2)\end{array}$ \\
\hline $\log$ Migration $_{i j}$ & $0.100^{* *}$ & $0.125^{* * *}$ \\
& $(0.047)$ & $(0.038)$ \\
$\log$ Migration $_{i j} *{\text { (Non-Developed Country })_{j}}$ & 0.058 & $0.145^{* * *}$ \\
$\log$ Distance $_{i j}$ & $(0.042)$ & $(0.038)$ \\
& $-0.744^{* * *}$ & $-0.265^{* * *}$ \\
Obs. & $(0.110)$ & $(0.050)$ \\
Obs with Developed Borrowing Countries & 1,451 & 1,588 \\
No. of Lending Countries & 427 & 431 \\
No. of Borrowing Countries & 17 & 17 \\
$R^{2}$ & 158 & 158 \\
Estimator & 0.86 & 0.94 \\
\end{tabular}

This table estimates the effect of migration on loans with interaction with non-developed countries. $N, L$ and $B$ denote number of observations, number of lending (investing) countries and number of borrowing (issuing) countries, respectively. Regressions are estimated by OLS and Poisson. Standard errors are clustered at the borrowing country level. All columns include country fixed effects, colonial link, language and legal origin as additional controls. 
Their results, therefore, strongly suggest that the channel through which migration affects bilateral financial flows is the information channel. Indeed, they find that the effect of migration on financial flows is strongest where informational problems are more acute. This is the case when comparing asset types that differ in terms of informational sensitivity (e.g., short versus long term bonds), country pairs characterized by different levels of cultural proximity (e.g., countries sharing versus not sharing a common language), migrants' source countries characterized by more information imperfections (i.e., developing countries) and types of migrants that differ in their ability to disseminate information across borders (e.g., high-skill versus low-skill migrants). Overall, the results suggest that migration contributes to reduce home bias and information frictions across countries.

\section{Migration and knowledge diffusion}

The sociological literature (e.g., Gaillard and Gaillard, 1997, Meyer, 2001) has long recognized that the migration of scientists can facilitate the international diffusion of knowledge and technology, be it directly, through brain circulation, or indirectly through the creation and development of scientific knowledge networks. For developing countries, this network externality is likely to affect mainly technological adoption (rather than innovation per se). Recent quantitative research in the geography of innovation has traditionally explored the role of social ties in facilitating knowledge diffusion, and in determining its spatial reach. Patent and inventor data have for long played a central role in quantitative contributions, with patent citations being used as a proxy for knowledge flows, and information of inventors proving a reliable means to geo-localize the invention effort (Jaffe et al., 1993; Thompson and Fox-Kean, 2005; Singh and Marx, 2013). Another way to track knowledge diffusion is to follow the evolution of the export basket of countries and investigate whether the role of migration in that process (Bahar et al., 2014; Bahar and Rapoport, forthcoming).

Information on inventors has been used to measure social proximity, with instances of coinventorship witnessing of the existence of professional ties between individual inventors as well as more complex social structure of referral and advice -- co-authorship of one or more patents (Agrawal et al., 2006), networks of inventors (Breschi and Lissoni, 2009). At the same time, migration scholars have explored to what extent these diasporas contribute to innovation in their home 
countries, through international knowledge flows (Agrawal et al., 2011; Kerr, 2008; Branstetter et al., 2014).

In the spirit of the above on trade, FDI and other financial flows, two recent papers have proceeded to evaluate the potential for skilled emigration (measured using inventors' data) on the flow of technological and scientific knowledge: Kerr and Kerr (forthcoming), and Miguelez (2014). They reached similar conclusions. For example, Miguelez (2014) uses a standard gravity framework to investigate the effect of diaspora inventors networks on two outcomes of interest from the perspective of developing countries: collaborative patents between home and host countries (that is, co-inventorship), and R\&D offshoring (that is, collaborations between applicants in developed countries and inventors in developing countries). The author finds a strong and robust result on the former outcome but not on the latter, suggesting that the general argument as to why highly-skilled migrants in general, and inventors in particular, can alleviate information imperfections (e.g., reduce information asymmetries, create trust among parties) and, thus, promote knowledge diffusion, holds especially for knowledge of the tacit-type. The point-estimates for co-inventorship are high but reasonable. The results are shown to be not driven by India and China on the side of source countries or by the United States as receiving country. This is an important result because previous literature (e.g., Kerr 2008, Agrawal et al. 2011 - both already cited) had focused on the India/ChinaUS relationship, with the implicit assumptions that other country-pairs are less relevant. These papers, therefore, document a new channel for brain gain which nicely complements what had already been uncovered (and detailed in the previous sections of this paper) for trade and financial flows.

Finally, Bahar and Rapoport (forthcoming) adopt another perspective on migration and knowledge diffusion: they posit that at least for the "tacit" part of knowledge - the one which requires direct human interaction to occur --, the pattern of international knowledge diffusion should follow the pattern of international migration. Following Bahar et al. (2014), they use export growth and export "jumps" at the product level to track the diffusion of innovation. More precisely, they assume that if a country goes from zero or close to zero Relative Comparative Advantage to RCAs greater than unity or higher, this is indicative of technological progress. They show that the likelihood for a

\footnotetext{
${ }^{3}$ Export jumps refer to likelihood of adding a new product to a country's export basket in the next ten year period.
} 
country to experience such "jumps" within a 5-year period is positively associated with the number of immigrants coming from and of emigrants going to countries with very high RCAs for the product considered in the previous period.

\section{Conclusion}

The "migration" component of globalization has long been seen either as a safety net (allowing to export one's demographic surplus and receive insurance income from remittances) or as a threat (in the case of brain drain) for developing countries. Recent research suggests that migration must also be seen as a way for emerging and developing countries to integrate further into the world economy. In particular, in the light of recent empirical evidence, the role of migration and diaspora networks must be considered as a potentially significant generator of brain gain. This paper reviews a growing and important series of studies demonstrating time and again the trade-creating effect of migration not just for goods but also for financial (especially FDI) and knowledge flows. As we have seen, the evidence supports an interpretation in terms of informational channel and confirms the comparative advantage of skilled migrants in this respect. Overall, our review of the literature suggests that migrants largely contribute to the integration of their home-countries into the global economy.

Access to foreign markets, sources of foreign investments and global knowledge networks are essential ingredients to the growth and development prospects of low and middle-income countries. This is precisely what migrants - and skilled migrants in particular - bring about. Migration and diaspora networks are a major component of the economic integration of developing countries into the global market. As transaction costs, risk premia and information imperfections are particularly prevalent in developing countries, the positive effects of diaspora networks can be crucial in overcoming these challenges. Thus, it is important to recognize these externalities to be able to exploit them.

\section{References}

Agrawal, A., Cockburn, I., McHale, J., 2006. Gone but not forgotten: knowledge flows, labor mobility, and enduring social relationships. Journal of Economic Geography 6, 571-591.

Agrawal, A., Kapur, D., McHale, J., Oettl, A., 2011. Brain drain or brain bank?The impact of skilled emigration on poor-country innovation. Journal of Urban Economics 69, 43-55. 
Agrawal, Ajay, et al. "Brain drain or brain bank? The impact of skilled emigration on poor-country innovation." Journal of Urban Economics 69.1 (2011): 43-55.

Aroca, Patricio, and William F. Maloney. "Migration, trade, and foreign direct investment in Mexico." The World Bank Economic Review 19.3 (2005): 449-472.

Aviat, Antonin and Nicolas Coeurdacier, "The geography of trade in goods andasset holdings," Journal of International Economics 71 (2007) 22-51.

Bahar, D., R. Hausmann, and C.A. Hidalgo. 2014. "Neighbors and the Evolution of the Comparative Advantage of Nations: Evidence of International Knowledge Diffusion?" Journal of International Economics 92, no. 1:111-123.

Bahar, D. and H. Rapoport (forthcoming). "Migration, knowledge diffusion and the comparative advantage of nations, Economic Journal, forthcoming.

Beine, M., F. Docquier and H. Rapoport (2007): Measuring international skilled migration: new estimates controlling for age of entry, World Bank Economic Review, 21, 2: 249-54.

Bhagwati, Jagdish, and Koichi Hamada. "The brain drain, international integration of markets for professionals and unemployment: a theoretical analysis." Journal of Development Economics 1.1 (1974): 1942.

Blonigen, B. A. (2001, February). In search of substitution between foreign productionand exports. Journal of International Economics 53 (1), 81-104.

Brainard, S. L. (1997). An empirical assessment of the proximity-concentration trade-offbetween multinational sales and trade. American Economic Review.

Branstetter, L., Li, G., \& Veloso, F. (2014). The Rise of International Co-invention. In The Changing Frontier: Rethinking Science and Innovation Policy. University of Chicago Press.

Branstetter, L., Li, G., Veloso, F., 2014.The Rise of International Co-invention (NBER Chapters).National Bureau of Economic Research, Inc.

Breschi, S., Lissoni, F., 2009. Mobility of skilled workers and co-invention networks: an anatomy of localized knowledge flows. Journal of Economic Geography 9, 439-468. doi:10.1093/jeg/lbp008

Coeurdacier, Nicolas and Helene Rey, "Home Bias in Open Economy Financial Macroeconomics," Journal of Economic Literature, 51(1), 2013, 63-115.

Combes, Pierre-Philippe, Miren Lafourcade, and Thierry Mayer. "The trade-creating effects of business and social networks: evidence from France." Journal of International Economics 66.1 (2005): 1-29.

Docquier, Frédéric, and Hillel Rapoport. "Globalization, brain drain, and development." Journal of Economic Literature (2012): 681-730.

Felbermayr, G. J. and F. Toubal (2012) "Revisiting the Trade-Migration Nexus: Evidence from New OECD Data", World Development 40(5), pp. 928-937.

Felbermayr, Gabriel, and Benjamin Jung. "Trade intermediation and the organization of exporters." Review of International Economics 19.4 (2011): 634-648.

Foley, C. Fritz, and William R. Kerr. Ethnic innovation and US multinational firm activity. No. w17336. National Bureau of Economic Research, 2011.

Gaillard, J. and Gaillard, A.M. (1997): The international mobility of brains: exodus or circulation?, Science Technology and Society, 2, 2: 195-228. 
Gould, David M. "Immigrant links to the home country: empirical implications for US bilateral trade flows." The Review of Economics and Statistics (1994): 302-316.

Hanson, G. H., R. J. Mataloni, and M. J. Slaughter (2005, November). Vertical productionnetworks in multinational firms. The Review of Economics and Statistics 87 (4),664-678.

Hatton, Timothy J., and Jeffrey G. Williamson. 1998. The Age of Mass Migration: Causes and Economic Impact. Oxford University Press, USA.

Head, Keith, and John Ries. "Immigration and trade creation: econometric evidence from Canada." Canadian journal of economics (1998): 47-62.

Helpman, E., M. J. Melitz, and S. R. Yeaple (2004, March). Export versus fdi withheterogeneous firms. American Economic Review 94 (1), 300-316.

Helpman, E., M. Melitz, and Y. Rubinstein (2008). Estimating trade flows: Tradingpartners and trading volumes. The Quarterly Journal of Economics 123 (2), 441-487.

Iranzo, Susana, and Giovanni Peri. "Migration and trade: Theory with an application to the Eastern-Western European integration." Journal of International Economics 79.1 (2009): 1-19.

Jaffe, A.B., Trajtenberg, M., Henderson, R., 1993.Geographic Localization of Knowledge Spillovers as Evidenced by Patent Citations. The Quarterly Journal of Economics 108, 577-598.

Javorcik, Beata S., et al. "Migrant networks and foreign direct investment." Journal of Development Economics 94.2 (2011): 231-241.

Kerr, W. and S. Kerr (forthcoming): Global Collaborative Patents, Economic Journal, forthcoming.

Kerr, W.R., 2008. Ethnic Scientific Communities and International Technology Diffusion. Review of Economics and Statistics 90, 518-537.

Kerr, William R. "Ethnic scientific communities and international technology diffusion." The Review of Economics and Statistics 90.3 (2008): 518-537.

Koenig, Pamina (2009). "Immigration and the export decision to the home country." Paris School of Economics, Working Paper No 2009-31.

Kugler, Maurice, and Hillel Rapoport. "International labor and capital flows: Complements or substitutes?." Economics Letters 94.2 (2007): 155-162.

Kugler, Maurice, and Hillel Rapoport "Migration, FDI and the Margins of Trade", Center for International Development Working Paper No 222, Harvard University, July 2011.

Kugler, Maurice, Oren Levintal, and Hillel Rapoport. "Migration and cross-border financial flows." (2013).

Lane, Philip R., and Gian Maria Milesi-Ferretti, "International Investment Patterns,' Review of Economics and Statistics, 90:3 (2008), 538--549.

Lipsey, R. E., Feenstra, R. C., Hahn, C. H., \& Hatsopoulos, G. N. (1999). The role of foreign direct investment in international capital flows. In International capital flows (pp. 307-362). University of Chicago Press.

Livi-Bacci, M. (2012): A Short History of Migration, Wiley.

Melitz, M.J. (2003): The Impact of Trade on Intra-Industry Reallocations and Aggregate Industry Productivity, Econometrica, 71, 6: 1695-1725.

Meyer, J.-B. (2001): Network approach versus brain drain: lessons from the Diaspora, International Migration, 39, 5: 91-110. 
Miyagiwa, Kaz. "Scale economies in education and the brain drain problem." International Economic Review (1991): 743-759.

Miguélez, E., 2014. Inventor Diasporas and the Internalionalization of Technology, CReAM Discussion Paper No. 1425, University College London.

Özden, C.., Parsons, C.R., Schiff, M., Walmsley, T.L., 2011. Where on Earth is Everybody? The Evolution of Global Bilateral Migration 1960-2000. World Bank Econ Rev 25, 12-56.

Parsons, Christopher, and Pierre-Louis Vézina (forthcoming). Migrant networks and trade: The Vietnamese boat people as a natural experiment. Economic Journal, forthcoming.

Portes, Richard, and Helene Rey, "The Determinants of Cross-Border Equity Flows,' Journal of International Economics 65:2 (2005), 269--296.

Rauch, James E., and Alessandra Casella. "Overcoming Informational Barriers to International Resource Allocation: Prices and Ties*" The Economic Journal 113.484 (2003): 21-42.

Rauch, James E., and Vitor Trindade. "Ethnic Chinese networks in international trade." Review of Economics and Statistics 84.1 (2002): 116-130.

Singh, J., Marx, M., 2013. Geographic Constraints on Knowledge Spillovers: Political Borders vs. Spatial Proximity. Management Science 59, 2056-2078.

Thompson, P., Fox-Kean, M., 2005. Patent Citations and the Geography of Knowledge Spillovers: A Reassessment. The American Economic Review 95, 450-460.

Tong, Sarah Y. "Ethnic networks in FDI and the impact of institutional development." Review of Development Economics 9.4 (2005): 563-580. 